\title{
Effect of Technology Enhanced Conceptual Change Texts on Students' Understanding of Buoyant Force ${ }^{i}$
}

\author{
Gulbin Ozkan ${ }^{1, *}$, Gamze Sezgin Selcuk² \\ ${ }^{1}$ Faculty of Education, Yildiz Technical University, Turkey \\ ${ }^{2}$ Buca Faculty of Education, Dokuz Eylul University, Turkey
}

Copyright (C) 2015 by authors, all rights reserved. Authors agree that this article remains permanently open access under the terms of the Creative Commons Attribution License 4.0 International License

\begin{abstract}
In this study, the effect of technology enhanced conceptual change texts on elementary school students' understanding of buoyant force was investigated. The conceptual change texts (written forms) used in this study are proven for effectiveness and are enriched by using technology support in this study. These texts were tried out on two groups. A pre-test/post-test quasi-experimental design and one control group $(n=20)$ and one experimental group $(n=20)$ were used. Experimental group were given the technology enhanced conceptual change texts, whereas the control group was taught in the traditional instruction. Data were collected five open-ended questions concerning buoyancy. When the results of the study were examined as to the conceptual understanding attained in the two groups, it was found that experimental group's conceptual understanding was higher than that of traditional instruction group. It is believed that these texts about "buoyant force," an often misunderstood subject in science education, are very useful class materials that can enable students to learn meaningfully.
\end{abstract}

Keywords Conceptual Change Text, Technology, Science Education, Buoyancy

\section{Introduction}

It is very important to properly identify the misconceptions in science education like in other domains. In a review of the literature many studies can be seen, where it has been observed that students enter the learning environment with many misconceptions about topics in physics such as mechanics, optics, electricity, and others [e.g., 1-4]. The topic of buoyant force, too, is one that encompasses both invisible and abstract conceptions and about what students have misconceptions.

Students' daily lives and experiences, their systems of belief and learning environments, their efforts to grasp concepts using their as yet immature mental skills and other factors conflict with the nature of science itself as well as with the process of how scientific knowledge emerges. In this process, students may attach incorrect meanings to scientific fact [44]. Different researchers use different terms of descriptions, such as misconceptions, preconceptions [45], alternative conceptions [46], children's scientific intuitions [47], children's science [48], common sense concepts [49] and spontaneous knowledge [50].

Using conceptual change approach is an effective teaching strategy to overcome misconceptions that it can be used throughout the teaching-learning process mainly because of its practical aspects.

The "Conceptual Change Approach" was set forth by Posner, Strike, Hewson and Gertzog [5]. This approach represents a perspective that is grounded on Piaget and Zeitgeist's views yet it has been improved by Posner and his colleagues.

The Conceptual Change Approach developed by Posner et al. [5] is based on four conditions:

1. Dissatisfaction: The student must be dissatisfied with the concept he knows; that is, he must realize that it is inadequate.

2. Intelligibility: The new concept must be understandable enough for the student.

3. Plausibility: The student must find the new view/concept logical and be able to picture it in his/her mind.

4. Fruitfulness: The new concept must be efficient; in other words, the student must be able to solve similar problems with this new concept.

One of the conceptual change approach strategy is conceptual change texts. Texts that are used to introduce theories that will convince students that they have misconceptions about certain scientific facts for the purpose of making these misconceptions conform to scientific concepts are called "conceptual change texts" [6]. Conceptual change texts specify students' misconceptions, clarify their reasons, and explain why they are incorrect by using concrete examples [7].

Like in conceptual change text instruction, in technology-enhanced student-centered learning 
environments, a deeper understanding of cognitive requirements and associated learning tasks are necessary [8].

Technology-enhanced learning environments often facilitate the understanding of abstract concepts by concrete experience [9]. Today's learning approaches have focused on students' interest to enable their retention. Computer assisted instruction is widely seen as an important educational tool in achieving this goal [10].

Visuals promote a student's ability to organize and process information [11]. Technology provides visuals and opportunities for teachers to meet the needs of students with various learning styles [12].

Blumenfeld et al. [13] stated these contributions that technology can make to the learning process: enhancing interest and motivation, providing access to information, allowing active, manipulable representations, structuring the process with tactical and strategic support diagnosing and correcting errors and managing complexity and aiding production.

Student engagement is critical to student motivation during the learning process. Numerous factors influence student motivation including teacher motivation and skills, visually and effective use of technology [14]. Computer enhanced conceptual change texts are believed to provide these factors.

In the last ten years, some development and improvement efforts have been attempted in the Turkish education system. The Science and Technology Curriculum in Turkey emphasizes that students should be active learners if what is taught is to be meaningful and retained. The reason the technology, prepared on the basis of the Curriculum, was made the center of the activity is so that students could be prompted into active participation in class. The program recommended by Turkish Ministry of National Education aimed to identify instructional objectives that enhance students' problem solving skills. The goal was to have students learn by experiencing and the result of the teaching was reviewed in terms of effectiveness. It is considered that both conceptual change text and technology-supported learning can achieve these objectives especially buoyant force topics which include abstract concepts.

The topic of buoyancy is a familiar realm that students have had experience with in many aspects of their lives, one which they find interesting; it is a subject that forms the basis of courses of primary school education [39]. In addition, a review of the literature shows that students have many misconceptions about the subject of buoyancy [e.g, 2, $40,41,42,43]$. Studies on buoyancy reveal that students have various misconceptions, such as "buoyancy increases as the amount of liquid increases," "buoyancy depends on the size of an object" and "gases do not exert a buoyant force".

This study aimed to use both conceptual change approach and technology-supported learning combined with the acquisition of a significant positive impact on student meaningful learning. There have been numerous studies to investigate the effect of conceptual change text on students' understanding and alternative conceptions [e.g., 15-20, 35, $36,39,44]$. Furthermore, there are numerous studies about computer-aided instruction [e.g., 21-25]. However, studies in which conceptual change text is combined with technology are limited [26]. The core of this research is the implementation of a technology enhanced conceptual change text on misconceptions in buoyancy. Furthermore, the contribution of this research to the field of science education is to provide information instructors on the beliefs of students' buoyancy concepts, so that instructors may know how to target misconceptions more effectively.

\section{Materials and Methods}

A pre-test/post-test quasi-experimental design with a nonequivalent control group and one control group $(n=20)$ and one experimental group $(n=20)$ were used. The research was carried out with two groups, one study group and one control group. In the study group, the technology enhanced conceptual chance text group, buoyant force concepts to be taught were introduced by using conceptual change texts. In the control group, this topic was taught using traditional teaching methods.

\subsection{Research Group}

The research was conducted in an elementary school located in the province of Istanbul, Turkey. The research group was formed $8^{\text {th }}$ grade students that their ages change from 13 to 15 . The two classes of the school where the research took place were grouped into the study and control groups without prejudice.

\subsection{Measure Instrument}

The five open-ended questions was prepared on the subjects of buoyancy was developed to define the students' misconceptions and measure their conceptual achievement. In developing the questionnaire, care was taken to maintain content validity in line with the concepts recommended by the Turkish Ministry of Education (2013) for the Elementary School instruction program. To test the content and face validity, the questionnaire was reviewed by three physics teachers from two different elementary schools (with more than 10 years of experience) and two faculty members specialized in physics instruction. Also, before testing for validity and reliability, a pilot run was implemented with 5 students to see whether there was anything the students could not understand. The question below is an example from the open-ended questionnaire (Table 1):

Table 1. Example of a Test Item on the Open-ended Questionnaire

Q1: The weight of a tennis ball is measured with the dynamometer in two different mediums. What can you tell about the weight of the ball whose weight was calculated as 50 Newton in an airless environment in an environment with air?

Please explain your answer. 


\subsection{Materials}

The students may have had two conceptual change texts designed to eliminate the misconceptions. These texts were developed by the researchers. These texts are about buoyancy in liquids and buoyancy in gases. The conceptual change texts were developed according to the Conceptual Change Approach introduced by Posner et al. [5] that is based on the conditions of dissatisfaction, intelligibility, plausibility and fruitfulness.

After the texts were prepared, two physics instructors with more than 10 years of professional experience and two faculty members specialized in physics education were enlisted to offer their views. In line with the opinions of the specialists, it was established that the prepared texts were appropriate to the academic level of the students and their knowledge. A pilot study was then launched. During the pilot study, the students were asked if there was anything in the texts that they could not understand; no question was raised during the implementation of the texts.

Videos for technology enhanced conceptual change texts prepared by the researchers. For explanation parts in the text to provide meaningful learning; videos are adjusted in the way to reflect the scope of the text thoroughly. For this aim, researchers consulted experts. With this aim, two physics instructors with more than 10 years of professional experience and two faculty members specialized in physics education were asked to offer their views.

\subsection{Procedure}

The research was conducted in the spring semester of the 2014-2015 academic year. The duration of the study was a total of two lessons. In two groups, an open-ended questionnaires pretest and posttest was administered before and after the implementation. The study experiment was initiated immediately after the pretesting. The same researcher (the first researcher) taught both of the groups. Both groups were instructed for an equal length of time. At the beginning of teaching open-ended questions was applied to students.

The instruction using the conceptual changes texts started by handing out to the students the worksheets which contained the first tier of the conceptual change texts. Once the worksheets were distributed, the students were told that they were to follow the instructions on the sheets. After each student received a sheet, a volunteer was called upon to read the text out loud. The objective of this was to encourage the participation of the students in the class. After the text was read, the video was watched. The videos and presentations of conceptual change along with worksheets are correlated in a design package. The videos were prepared by researchers with the aim of visualizasyon. They included introduction of the texts questions' answers and students' misconceptions and what are the correct concepts. The researcher acted as a guide throughout the process and, instead of correcting the students' mistakes, led the students to finding the right answers by themselves. After the topic was covered, the researcher collected the students' worksheets for a review. At the end of every section, the sample questions prepared by the researcher were answered together with the students.

In the control group, before each class started, the students were asked a question to motivate them. The researcher conducted the lessons here in this group, but only by using the method of lecturing. It was the teacher who played an active role over the course of the session. At the end of every topic, the sample questions prepared by the researcher were answered together with the students.

Open-ended questions as a posttest were dispersed again to both groups.

\subsection{Data Analysis}

In the analysis of the open-ended questions in the questionnaire, the students' responses were defined thematically. Content analysis of the data was performed by two researchers.

\section{Results}

In this part, the conceptual change texts' features and implementation process is presented. One of those texts is presented with explanations. Additionally, misconceptions and the effect of the texts over students' concept changes are presented.

\subsection{The Technology Enhanced Conceptual Change Texts Instrument Design}

This study presents two examples of technology enhanced conceptual change texts instruction sample that primary science teachers will benefit from throughout the teaching/learning process. The conceptual change texts (written forms) used in this study are proven for effectiveness [27] and are enriched by using technology support in this study.

The conceptual change text designed is made up of five parts and has been planned in accordance with the conditions of dissatisfaction, intelligibility, plausibility and fruitfulness in the conceptual change approach developed by Posner et al [5]. It is recommended that students be given those parts separately so that they cannot read the answer in the next part and change their answers accordingly.

The teacher starts the teaching-learning process by handing out worksheets that include the first step of the conceptual change texts. Subsequently, the students are told to follow the instructions carefully. Since the purpose of this exercise is to diagnose and overcome the misconceptions the students have, it is of the utmost importance that the teacher recommends that the students study individually, not in pairs or in groups with their friends. After distributing the texts, the teacher may ask a volunteer to read the text aloud. 
Additionally, the students will hear what their friends think about the subject matter, and they will all have a chance to correct their friends' mistakes if any are made. Throughout this period, the teacher must be a guide. He/She must not correct students' mistakes directly, but encourage them to discover the reasons for their mistakes by offering clues.

The first part of the texts aims to identify any possible misconceptions students may have. This allows a teacher to understand how a student pictures the concept in his/her mind. The aim of this chapter is to create an inconsistency that is, dissatisfaction.

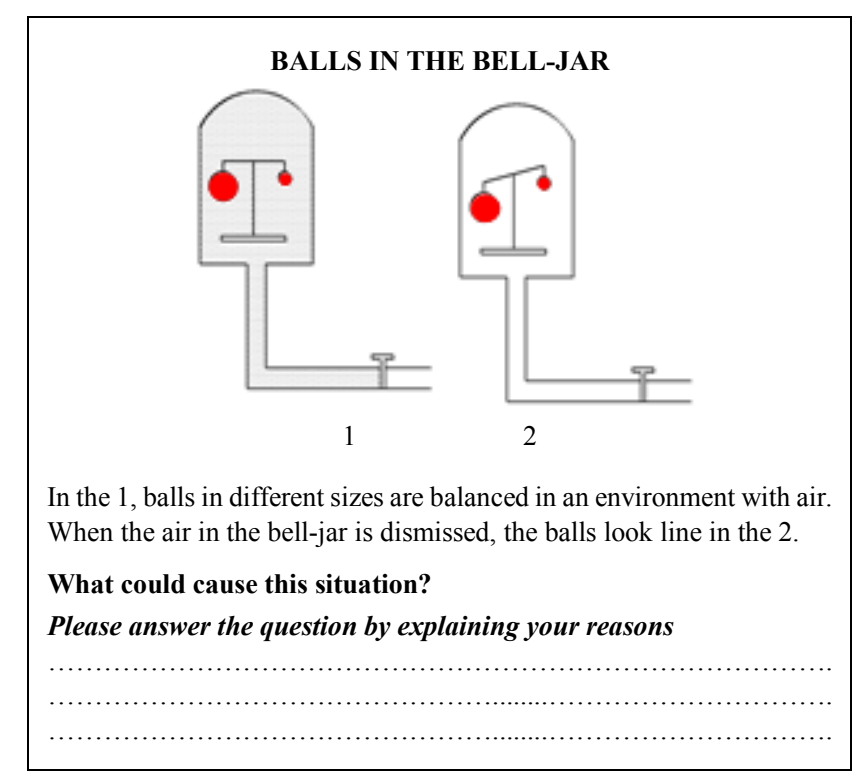

Figure 1. First part of the text

During the implementation, a discussion environment is supplied in the classroom and students are ensured to grasp the problem situation thoroughly.

Second part features common misconceptions and answers that are scientifically wrong.

The most frequent answer about this is "As the density of the big balloon is bigger than the small balloon, it is lower" misconception. What about you? What do you think? Now, read the next text very carefully.

Figure 2. Second part of the text

After students give the problem a second thought, the scientific truths concerning the subject are explained. That explanation must be very clear and intelligible. In this section, arrangement should be made as taking into consideration Posner et al.'s [5] intelligibility and plausibility principle. The video associated with the text is watched by students after this third part of the text is read. By this means, students, who learns both visually and auditory, comprehend the concepts. Supporting conceptual change texts with the technology interfere with just read the text without understanding.

\begin{abstract}
Let's see if your answer is correct
Air lifts things in it with buoyancy like liquids. However, the buoyancy of the air is as much as the weight of the air equal to the size of things. So, for the air to be able to lift a thing, the density of the thing should be less than the density of the air. For this, in the balloons wanted to be lifted in the air:

* Either are filled with a gas like hidrojen, helium whose density is lesser than the air

* Or the air is expanded by heating (the heated air is expanded and its density is lessened).

\section{Buoyancy of Air}

$\mathrm{F}_{\text {buoyancy }}=\mathrm{V}_{\text {disp. }} \mathrm{d}_{\text {gas }} \cdot \mathrm{g}$ is calculated with this.

The reason of observing the shape given above is bigger buoyancy is on the thing with a bigger size and weight. As this force is omitted when the air is dismissed, the thing with a bigger size is lowered.

- If the weight of a thing is bigger than the buoyancy of the air, the thing is lowered. $\left(\mathrm{G}_{\text {object }}>\mathrm{F}_{\text {buoyancy }}\right)$

- If the buoyancy of the air is equal to the weight of a thing, the thing is hanged in the air.. $\left(\mathrm{G}_{\text {object }}=\mathrm{F}_{\text {buoyancy }}\right)$

- If the weight of a thing is lesser than the buoyancy of the air, the thing gets higher. $\left(\mathrm{G}_{\text {object }}<\mathrm{F}_{\text {buoyancy }}\right)$

We see some balloons rising in the air when they are left free. This situation means that the air implements buoyancy on the balloon.
\end{abstract}

Figure 3. Third part of the text

In the fourth part, when students perceive the difference between misconceptions and scientifically true explanations, they are asked to express their own opinions. The aim in this part is to measure how much awareness has been raised among students and see if they still have some question marks in their minds or not.

Did you change your mind after reading the text? If you did, please express your views once again considering the text now, and give an example.

(n.



Figure 4. Forth part of the text

In last part, the purpose is to understand whether or not the students have grasped the text well. In this section, Posner et al [5] based on the fruitfulness principles, the new problem situations are provided to solve. Students can transfer knowledge to new problems situation, learned knowledge is permanent.

\section{Now, let's answer the following questions: \\ I. Does the air have buoyancy? Explain.}

II. What would happen if the same scales in the non-air environment in the shape given above were taken to the air environment after it was balanced?

III. In this situation, which environment gives the real weights of the things? Why?

IV. How could the hot-air balloons move up?

.

Figure 5. Fifth part of the text 
Table 2. Frequency of Students' Misconceptions

\begin{tabular}{|c|c|c|c|c|c|c|}
\hline \multirow{2}{*}{ Misconceptions } & \multicolumn{3}{|c|}{ Control Group } & \multicolumn{3}{|c|}{ Experimental Group } \\
\hline & Pre & Post & $\mathrm{CC}$ & Pre & Post & $\mathrm{CC}$ \\
\hline $\begin{array}{l}\text { 1. The buoyant force exerted on sinking and floating objects is equal to } \\
\text { the weight of the object. }\end{array}$ & $10(\% 50)$ & $5(\% 25)$ & $5(\% 25)$ & $9(\% 45)$ & $4(\% 20)$ & $5(\% 25)$ \\
\hline $\begin{array}{l}\text { 2. The buoyant force in sinking objects is less than the buoyant force in } \\
\text { floating objects because the weight of a sinking object is greater. }\end{array}$ & $9(\% 45)$ & $5(\% 25)$ & $4(\% 20)$ & $9(\% 45)$ & $4(\% 20)$ & $5(\% 25)$ \\
\hline $\begin{array}{l}\text { 3. When the density of a liquid is reduced, the floating object will sink } \\
\text { less. }\end{array}$ & $4(\% 20)$ & $1(\% 5)$ & $3(\% 15)$ & $6(\% 30)$ & $1(\% 5)$ & $5(\% 25)$ \\
\hline $\begin{array}{l}\text { 4. The buoyant force exerted on floating and suspended objects is the } \\
\text { same and greater than the buoyant force applied to sinking objects. }\end{array}$ & $4(\% 20)$ & $2(\% 10)$ & $2(\% 10)$ & $4(\% 20)$ & $2(\% 10)$ & $2(\% 10)$ \\
\hline $\begin{array}{l}\text { 5. The buoyant force exerted on floating and suspended objects is the } \\
\text { same and less than the buoyant force applied to sinking objects. }\end{array}$ & $5(\% 25)$ & $3(\% 15)$ & $2(\% 10)$ & $4(\% 20)$ & $2(\% 10)$ & $2(\% 10)$ \\
\hline $\begin{array}{l}\text { 6. When an object that has sunk is the heaviest, it is because the greatest } \\
\text { buoyant force has been applied to it. }\end{array}$ & $8(\% 40)$ & $3(\% 15)$ & $5(\% 25)$ & $9(\% 45)$ & $2(\% 10)$ & $7(\% 35)$ \\
\hline 7. As in the oceans, objects sink less when there is more water. & $10(\% 50)$ & $4(\% 20)$ & $6(\% 30)$ & $9(\% 45)$ & $3(\% 15)$ & $6(\% 30)$ \\
\hline 8. Buoyant force depends on the shape of an object. & $6(\% 30)$ & $2(\% 10)$ & $4(\% 20)$ & $7(\% 35)$ & $1(\% 5)$ & $6(\% 30)$ \\
\hline 9. Buoyant force depends on the shape of a container. & $5(\% 25)$ & $1(\% 5)$ & $4(\% 20)$ & $5(\% 25)$ & $0(\% 0)$ & $5(\% 25)$ \\
\hline 10. Gases do not exert a buoyant force. & $13(\% 65)$ & $7(\% 35)$ & $6(\% 30)$ & $12(\% 60)$ & $2(\% 10)$ & $10(\% 50)$ \\
\hline 11. Buoyancy in gases does not depend on medium. & $6(\% 30)$ & $2(\% 10)$ & $4(\% 20)$ & $7(\% 35)$ & $2(\% 10)$ & $5(\% 25)$ \\
\hline
\end{tabular}

Note: CC: Conceptual Change

\subsection{Findings Obtained from the Paper-and-pencil Questionnaire}

In order to find out students' perceptions of concepts and events regarding buoyancy, the questions in the questionnaire were analyzed in detail and can be seen underneath the related category.

The misconceptions found in the document analysis that could see in a comparison of the pre- and post-tests are summarized in Table 2.

When the conceptual change frequency of the students from before the instruction to after the instruction are considered in Table 2, it is seen that the biggest change was in the experimental group. It was observed that just one misconception did not change.

\section{Conclusions and Discussion}

In this study, the researchers presented technology enhanced two conceptual change texts instruction sample that can be used to overcome some common misconceptions regarding buoyancy. These materials were tested using two small groups of students, and included qualitative data based on only the students' statements. The main limitations of the study were that it tried in just two lessons and this was not a long-term study.

There also were a number of other alternative conceptions about buoyancy identified in this study. The pretest results of the research showed that all of the students had some misconceptions or difficulty with understanding. In addition, it was also found that two groups displayed similar misconceptions. After the instruction, it was seen that some of the misconceptions the students had were still present. It was however observed that the number of misconceptions had been reduced or eliminated altogether in two groups. After the instruction, it was seen that none of the students formed new misconceptions.

It was determined that the effectiveness of conceptual change in misconceptions was the same in both groups. This situation shows that promoting conceptual change for some concepts is difficult $[52,53]$. This result is parallel of the literature [30]. Furthermore, unexpected results such as misconceptions labelled 10 that the control group appeared to perform better in the post-test were found. However, the experimental group' conceptual change is higher than control group. In light of these results, it can be said that the technology enhanced conceptual change texts, were more successful in overcoming the students' misconceptions than the traditionally designed instruction.

The reason why the scores of technology enhanced conceptual change approach were higher than traditional approach could be that students were involved in activities that helped them activate their prior knowledge and struggle with their misconceptions. These activities also provide evidence that students' initial conceptions are insufficient. The important part in this approachwas the intensive teacher-student interaction. Such a student centered environment provides opportunities for greater involvement, thereby giving students more chances to gain insights and self-efficacy, and students are allowed to focus on learning and understanding [51].

It can be said that the researcher observed that of technology enhanced conceptual change group had more motivation and interested the activities.

Technology enhanced conceptual change approach group' students could became dissatisfied with their existing 
conceptions. They could have accepted the new concept in an easier way when they experienced dissatisfaction about their existing concept. Moreover, in the conceptual change approach, students can use what they learn from the texts in new situations they face, which is different from context based approach. This could have led students understand the concepts meaningfully.

When the effects of the conceptual change approach on conceptual change is compared with traditional instruction methods, it has been found in many studies that this approach has more positive impacts [e.g., 15, 28, 29, 30]. Furthermore, several efforts, in the science education, have demonstrated alternative roles for technology in teaching and learning [e.g., 31-33]. McCluskey [34] stated that technology has enormous potential for enhancing educational practice. These findings are similar to current research. Özmen [35] also reported that the studies related to comparison between computer-assisted instruction and traditional instruction shows that technology-based instruction strategies are more effective than the traditional ones.

Ozkan and Sezgin Selcuk [36] prepared two conceptual change texts within the principles of Posner et al. [5]. Conceptual change texts, which were developed about "sound" topic, were implemented on primary and secondary school students. In this study, students' positively changing conceptual understanding has been reached and as the result, it is determined to be an effective method of teaching conceptual change texts. In this study, students were positive change in conceptual understanding has been found and the result was determined to be an effective method of teaching conceptual change texts.

In literature some researchers stated that computer-assisted instruction in comparison to the conventional methods of teaching can enhance transfer learners' alternative conceptions and enhance understanding of scientific conceptions [37, 38].

With Technology now available for the use of teachers with their students in the classroom, interactive learning environments may provide a significant potential for meeting the needs of students with learning styles and for engaging students during the learning process.

It can be recommended that researchers should comply with the four conditions stated by Posner et al. [5] in order to make these conceptual change texts effective teaching tools. In addition, considering that there may be some students in class who have difficulty understanding what they read, the use of the material should definitely accompany classroom discussions.

The results of this research provided further evidence to support the findings in a growing body of literature indicating that students hold alternative conceptions on a variety of buoyancy concepts. In future studies, the same learning approach effectiveness on different learning outputs (attitude towards to course, learning motivation and learning retention etc.) can be examined.

Depending on the results of this study, such studies can be carried out as long term studies like one semester and after the interviews, the data may be compared each other.

\section{REFERENCES}

[1] Beichner, R. J. (1994). Testing student interpretation of kinematics graphs. American Journal of Physics, 62, $750-762$.

[2] Besson, U., \& Viennot, L. (2004). Using models at the mesoscopic scale in teaching physics: Two experimental interventions in solid friction and fluid statics. International Journal of Science Education, 26(9), 1083-1110.

[3] Eryilmaz, A. (2002). Effects of conceptual assignments and conceptual change discussions on students' misconceptions and achievement regarding force and motion. Journal of Research in Science Teaching, 39(10), 1001-1015.

[4] McDermott, L. C. (1991). What we teach and what is learned-Closing the gap. American Journal of Physics, 59, 301-315.

[5] Posner, G. J., Strike, K. A., Hewson, P. W., \& Gertzog, W. A. (1982). Accommodation of a scientific conception: Toward a theory of conceptual change. Science Education, 66(2), 211-227.

[6] Hynd, C. R. (2001). Refutational texts and the change process. International Journal of Educational Research, 35(7), 699-714.

[7] Guzzetti, B. J., Williams, W. O., Skeels, S. A., \& Wu, S. M. (1997) Influence of text structure on learning counterintuitive physics concepts. Journal of Research in Science Teaching, 34, 701-719.

[8] Hannafin, M.J. (1989). Interaction strategies and emerging instructional technologies: Psychological perspectives. Canadian Journal of Educational Communication, 18, $167-179$.

[9] Hannafin, M. J., \& Land, S. M. (1997). The foundations and assumptions of technology-enhanced student-centered learning environments. Instructional Science, 25(3), 167-202.

[10] Yiğit, N., \& Akdeniz, A. R. (2003). The Effect of computer-assisted activities on student achievement in physics course: Electric circuits sample. Gazi University Journal of Gazi Educational Faculty, 23(3), 99-113.

[11] McKendrick, J. H., \& Bowden, A. (1999). Something for everyone? An evaluation of the use of audio-visual resources in geographical learning in the UK. Journal of Geography in Higher Education, 23(1), 9-20.

[12] Bryant, S. M. and Hunton, J. E. (2000). The use of technology in the delivery of instruction: implications for accounting educators and education researchers. Issues in Accounting Education, 15(1), 129-163.

[13] Blumenfeld, P. C., Soloway, E., Marx, R. W., Krajcik, J. S., Guzdial, M., \& Palincsar, A. (1991). Motivating project-based learning: Sustaining the doing, supporting the learning. Educational Psychologist, 26(3-4), 369-398.

[14] Beeland, W. D. (2002, July). Student engagement, visual 
learning and technology: Can interactive whiteboards help. In Annual Conference of the Association of Information Technology for Teaching Education.

[15] Chambers, S. K., \& Andre, T. (1997). Gender, prior knowledge, interest, and experience in electricity and conceptual change text manipulations in learning about direct current. Journal of Research in Science Teaching, 34(2), $107-123$.

[16] Diakidoy, I. A. N., Kendeou, P., \& Ioannides, C. (2003). Reading about energy: The effects of text structure in science learning and conceptual change. Contemporary Educational Psychology, 28(3), 335-356.

[17] Başer, M., \& Geban, Ö. (2007). Effectiveness of conceptual change instruction on understanding of heat and temperature concepts, Research in Science and Technological Education, 25(1), 115-133.

[18] Dilber, R., Karaman, I., \& Duzgun, B. (2009). High school students' understanding of projectile motion concepts. Educational Research and Evaluation, 15(3), 203-222.

[19] Hırça, N. (2008). A review of the effect of material developed related to "work-power-energy" based on the 5E Model on conceptual change. Unpublished Doctorate Thesis, Atatürk University, Erzurum.

[20] She, H. C. (2003). DSLM instructional approach to conceptual change involving thermal expansion, Research in Science and Technological Education, 21(1), 43-54.

[21] Sanger, M. J., \& Greenbowe, T. J. (2000). Addressing student misconceptions concerning electron flow in electrolyte solutions with instruction including computer animations and conceptual change. International Journal of Science Education, 22, 521-537.

[22] Kelly, R. M., \& Jones, L. L. (2007). Exploring how different features of animations of sodium chloride dissolution affect students' explanations. Journal of Science Education and Technology, 16, 413-429.

[23] Bangert-Drowns, R. L., Kulik, J. A., \& Kulik, C. L. C. (1985) Effectiveness of computer-based education in secondary schools. Journal of Computer-based Instruction, 12(3), 59-68.

[24] Ferguson, N. H., \& Chapman, S. R. (1993). Computer-assisted instruction for introductory genetics. Journal of Natural Resources and Life Sciences Education, 22, 145-152.

[25] Fletcher-Flinn, C. M., \& Gravatt, B. (1995). The efficacy of computer assisted instruction (CAI): A meta-analysis. Journal of Educational Computing Research, 12(3), 219-241.

[26] Özmen, H. (2011). Effect of animation enhanced conceptual change texts on 6th grade students' understanding of the particulate nature of matter and transformation during phase changes. Computers \& Education, 57(1), 1114-1126.

[27] Ozkan, G., \& Sezgin Selcuk, G. S. (2013). The use of conceptual change texts as class material in the teaching of "sound" in physics. In Asia-Pacific Forum on Science Learning and Teaching, 14(1), Article 11.

[28] Coştu, B., Ayas, A., Niaz, M., Ünal, S., \& Çalik, M. (2007). Facilitating conceptual change in students' understanding of boiling concept. Journal of Science Education and Technology, 16(6), 524-536.
[29] Duit, R., \& Treagust, D. F. (2003). Conceptual change: a powerful framework for improving science teaching and learning. International Journal of Science Education, 25(6), 671-688.

[30] Sendur, G., \& Toprak, M. (2013). The role of conceptual change texts to improve students' understanding of alkenes. Chemistry Education Research and Practice, 14, 431-449.

[31] Levin, J. \& Waugh, M. (1987). Educational simulations, tools, games, and microworlds: Computer-based environments for learning. International Journal of Educational Research, 12(1), 71-79.

[32] Roth, W. M., \& Roychoudhury, A. (1993). The concept map as a tool for the collaborative construction of knowledge: A microanalysis of high school physics students. Journal of Research in Science Teaching, 30(5), 503-534.

[33] Linn, M. C., \& Muilenburg, L. (1996). Creating lifelong science learners: What models form a firm foundation?. Educational Researcher, 25(5), 18-24.

[34] McCluskey, L. (1994). Gresham's law: Technology and education. Phi Delta Kappan, 75(7), 550-552.

[35] Özmen, H. (2008). The influence of computer-assisted instruction on students' conceptual understanding of chemical bonding and attitude toward chemistry: A case for Turkey. Computers \& Education, 51(1), 423-438.

[36] Ozkan, G. (2011). The effects of conceptual change texts and real life context- based learning on students' approaches to learning physics and their conceptual understandings. Master Thesis, Dokuz Eylul University, Izmır, Turkey.

[37] Jimoyiannis, A., \& Komis, V. (2001). Computer simulations in physics teaching and learning: a case study on students' understanding of trajectory motion. Computers \& Education, 36(2), 183-204.

[38] Ronen, M., \& Eliahu, M. (2000). Simulation-A bridge between theory and reality: The case of electric circuits. Journal of Computer Assisted Learning, 16(1), 14-26.

[39] She, H. C. (2002). Concepts of a higher hierarchical level require more dual situated learning events for conceptual change: a study of air pressure and buoyancy. International Journal of Science Education, 24(9), 981-996.

[40] Havu-Nuutinen, S. (2005). Examining young children's conceptual change process in floating and sinking from a social constructivist perspective. International Journal of Science Education, 27(3), 259-279.

[41] Joung, Y. J. (2009). Children's typically-perceived-situations of floating and sinking. International Journal of Science Education, 31(1), 101-127.

[42] Parker, J., \& Heywood, D. (2000). Exploring the relationship between subject knowledge and pedagogic content knowledge in primary teachers' learning about forces. International Journal of Science Education, 22(1), 89-111.

[43] She, H. C. (2005). Enhancing eighth grade students' learning of buoyancy: The interaction of teachers' instructional approach and students' learning preference styles. International Journal of Science and Mathematics Education, 3(4), 609-624.

[44] Ercan, F., Taşdere, A., \& Ercan, N. (2010). Observation of cognitive structure and conceptual changes through word 
associations tests. Journal of Turkish Science Education, 7(2), 136-154.

[45] Novak, J. D. (1977). A Theory of Education. Ithaca, NY: Cornell University Press.

[46] Driver, R., \& Easley, J. (1978). Pupils and paradigms: A review of literature related to concept development in adolescent science students. Studies in Science Education, $5(1), 61-84$.

[47] Sutton, C. R. (1980). The learner's prior knowledge: a critical review of techniques for probing its organization. European Journal of Science Education, 2, 107-120.

[48] Gilbert, J. K., Watts, D. M., \& Osborne, R. J. (1982). Students' conceptions of ideas in mechanics. Physics Education. 17, 62-6.

[49] Halloun, I. A., \& Hestenes, D. (1985). Common sense concepts about motion. American Journal of Physics, 53(11), 1056-1065.
[50] Vygotsky, L. (1986). Thought and Language. Cambridge, MA: The MIT Press.

[51] Balci, S., Cakiroglu, J., \& Tekkaya, C. (2006). Engagement, exploration, explanation, extension, and evaluation (5E) learning cycle and conceptual change text as learning tools. Biochemistry and Molecular Biology Education, 34(3), 199-203.

[52] Campanario J. M., (2002), There parallelism between scientist' and students' resistance to new scientific ideas. International Journal of Science Education. 24(10), 1095-1110.

[53] Tsaparlis G. and Papaphotis G., (2009), High-school students' conceptual difficulties and attempts at conceptual change: the case of basic quantum chemical concepts. International Journal of Science Education, 31(7), 895-930. i A part of this paper was orally presented at the International Conference on
New Horizons in Education, 10-12/ June/2015, Barcelona Spain. 